Clin. eXPL. MEtastasis, 1985 , vol. 3, No. 1, 45-59

\title{
Attachment, spreading and growth in vitro of highly malignant and low malignant murine fibrosarcoma cells
}

\author{
JAMES VARANI*, IVAR AMUND GRIMSTAD \\ RANDALL N. KNIBBS $\dagger$, \\ TORSTEIN HOVIG \\ * Department of Pathology and †Department of Biological Chemistry, The \\ University of Michigan Medical School, Ann Arbor, Michigan 48109, U.S.A. \\ \$Institute of Pathology, University of Oslo, Rikshospitalet-The National \\ Hospital, N-0027, Oslo 1, Norway
}

(Received 14 November 1983; accepted 22 October 1984)

\begin{abstract}
Highly malignant cell lines and low-malignant cell lines isolated from three different methylcholanthrene-induced murine fibrosarcomas were examined for their ability to attach to plastic dishes and collagen-coated dishes under serumfree conditions and in the presence of serum. Most of the cells from the three highly malignant lines attached and spread under all conditions. By $72 \mathrm{~h}$, there was a significant increase in the number of cells indicating that at least some of the cells had undergone division (even in the absence of serum). In contrast, fewer of the cells from the three low-malignant lines attached and spread on the plastic or collagen substrates in the absence of serum or in the presence of 0.1 per cent serum. However, when $15 \mu \mathrm{g}$ laminin per dish was added along with the lowmalignant cells, they then attached and spread on the plastic and collagen-coated dishes. Previous studies have indicated that the highly malignant lines express cell surface antigens that cross-react with laminin while the low-malynant cell lines do not. We speculate that the differences between the high- and lowmalignant cells in the expression of cell surface laminin-like antigens contribute to the dissimilarities in attachment and spreading capacity. These differences may also contribute to the dissimilarity between these cells in malignant potential.
\end{abstract}

\section{Introduction}

Basement membranes and interstitial stroma form boundaries between discrete tissues in higher multicellular organisms. During the processes of invasion and metastasis, malignant tumor cells must cross these boundaries. How this occurs has not been fully delineated but current ideas suggest that tumor cell adhesion to the host tissues, local destruction of these tissues and active migration of the tumor cells into the spaces produced as a result of tissue dissolution are involved $[8,9]$. Different types of tumors have undoubtedly evolved a variety of mechanisms to carry out these functions. Studies by Terranova et al. [27] have suggested that laminin may be involved in the invasion and metastatic processes. They showed that in a population of unselected murine tumor cells, those cells which could use laminin as an attachment factor were much more metastatic than the cells which could not use laminin. It was subsequently shown that tumor cells which utilized laminin as an attachment factor had high-affinity surface receptors for the laminin molecule $[23,28]$. Thus it could be postulated that the presence of laminin receptors on the tumor cells allows the cells to bind directly to the laminin associated with type IV collagen in basement membranes. 
Previous studies in our laboratory have resulted in the isolation of highly malignant cell lines and low-malignant cell lines from each of three different methylcholanthrene-induced murine tumors [32-34]. The highly malignant cells from all three tumors express antigens on their surface which cross-react with laminin while there is no evidence of this material on the surface of the corresponding low-malignant cells $[13,34,35]$. We report here that the highly malignant cell lines are more adherent to plastic culture dishes and collagen-coated culture dishes than the low-malignant cell lines. We speculate that the expression of cell surface laminin or laminin-like antigens by tumor cells may facilitate their adherence to host tissue structures and thereby promote metastasis.

\section{Materials and methods}

\section{Cells}

Highly malignant cell lines and low-malignant cell lines were obtained from three different chemically induced murine fibrosarcomas and used in this study. The isolation and characterization of these populations have been described in previous reports [32-34]. The tumors from which the cell lines arose have been designated as tumor 1.0,1.1 and 1.2. The highly malignant cell lines have been designated as cell line $1.0 / \mathrm{L} 1,1.1$ and 1.2 . The $1.0 / \mathrm{L} 1$ cell line is a cloned line derived from a spontaneous lung metastasis which developed in a syngeneic ( $\mathrm{C} 57 \mathrm{~b} 1 / 6)$ mouse after subcutaneous injection of the parent 1.0 cells. The 1.1 and 1.2 lines are uncloned populations of cells which were established in culture by explanation of the 1.1 and 1.2 primary tumors. Low-malignant cell lines were obtained from each of the three parent tumor lines by selecting for resistance to complement-mediated cytotoxicity in the presence of antibodies to the human blood group B antigen. These cell lines have been designated as $1.0 /$ anti- $\mathrm{B}^{\mathrm{r}}, 1.1 /$ anti- $\mathrm{B}^{\mathrm{r}}$ and $1.2 /$ anti- $\mathrm{B}^{\mathrm{r}}$. The cells lines $1.0 / \mathrm{L} 1$ and $1.0 /$ anti- $\mathrm{B}^{\mathrm{r}}$ have been maintained in culture for several years and have been shown to be stable with regard to a number of functional characteristics [36]. The other cell lines are of recent origin [34]. In the present study all of the cell lines were maintained under identical conditions which included growth in RPMI-1640 medium supplemented with 10 per cent fetal bovine serum at $37^{\circ} \mathrm{C}$ in 5 per cent $\mathrm{CO}_{2} / 95$ per cent air. The cells were subcultured by trypsinization as necessary. Prior to use in these studies all of the cell lines were shown to be free of mycoplasma contamination by incubation in mycoplasma broth and on mycoplasma agar.

\section{Laminin and anti-laminin antibodies}

Laminin purified from the murine EHS sarcoma by two different methods [24, 31] was used in these studies. The laminin showed only two major bands, at $M_{\mathrm{r}}$ 200000 and 400000 , when examined by SDS-polyacrylamide gel electrophoresis under reducing conditions. Using an enzyme-linked immunosorbent assay (ELISA) [35], the laminin reacted with anti-laminin antibodies at dilutions from $1: 1$ to $1: 10^{6}$ but did not react with anti-fibronectin antibodies. Using a cell attachment assay [35], biological activity was demonstrated at concentrations as low at $2 \mu \mathrm{g}$ in $2 \mathrm{ml}$ per $35 \mathrm{~mm}$ (diameter) dish. Rabbit anti-laminin antisera was prepared by repeated intradermal injections of the purified laminin [13]. The IgG fraction of the antiserum was prepared using standard methodologies [7]. 


\section{Collagen-coated dishes}

Human placental (type IV) collagen was obtained from Sigma Chemical Company (St Louis, Missouri). The collagen had been prepared by the method of Glanville et al. [2]. Analysis of the collagen on 5 per cent SDS-polyacrylamide gels showed bands at 95000 and 70000 , consistent with the pattern reported previously $[2,26]$. Stock solutions of the collagen were prepared by solubilizing the purified material in $0 \cdot 1 \mathrm{~mol} / \mathrm{L}$ acetic acid at a concentration of $1 \mathrm{mg} / \mathrm{ml}$. At the time of use, the collagen was diluted to either $500 \mu \mathrm{g} / \mathrm{ml}, 200 \mu \mathrm{g} / \mathrm{ml}$ or $50 \mu \mathrm{g} / \mathrm{ml}$ in $0 \cdot 1 \mathrm{~mol} / \mathrm{L}$ acetic acid and $1 \mathrm{ml}$ was added to each of several $35 \mathrm{~mm}$ (diameter) bacteriological dishes. The acetic acid solution was evaporated from the dishes at $37^{\circ} \mathrm{C}$ allowing the collagen to be deposited on the surface. After sterilization under ultraviolet light for $2 \mathrm{~h}$, the dishes were washed two times in serum-free RPMI-1640 medium and were ready to use. Some of the dishes prepared with $50 \mu \mathrm{g}$ of the human placental type IV collagen were examined by transmission electron microscopy. For this, the collagen-coated dishes were fixed overnight in 2.0 per cent glutaraldehyde in $0.1 \mathrm{~mol} / \mathrm{L}$ cacodylate buffer without calcium at $\mathrm{pH} 7.2$ and postfixed for $5 \mathrm{~min}$ in 1.0 per cent osmium tetroxide in cacodylate buffer with calcium. Dehydration was performed in graded solutions of ethanol. In the embedding procedure, we did not include treatment with pure propylene oxide, because the plastic did not tolerate it. Treatment with a $1: 1$ mixture of Epon 812 (Ladd, Burlington, Vermont) and propylene oxide was for only about $3 \mathrm{~min}$ before this was exchanged with Epon 812 . Semi-thin $(2 \mu \mathrm{m})$ sections were stained with 1 per cent toluidine blue. Several different areas with or without cells were arbitrarily chosen for thin sectioning, and 50-60 $\mathrm{nm}$ sections were cut with a Reichert-Jung Ultracut E ultramicrotome and mounted on copper grids. The sections were stained with uranyl acetate and lead citrate and examined with a Jeol $100 \mathrm{~B}$ electron microscope. Electron microscopical examination indicated that the human placenta type IV collagen coat made with $50 \mu \mathrm{g}$ per $35 \mathrm{~mm}$ (diameter) dish was continuous (figure 1). Usually, the coat was approximately $60 \mathrm{~nm}$ thick (figure 1 (A)). Occasionally it was found to be up to $250 \mathrm{~nm}$ thick (figure 1 (B)). On uncoated control dishes, no layer could be seen between the plastic and the cells.

In certain experiments, plastic dishes coated with type IV collagen from the murine EHS sarcoma or with mouse skin (type I) collagen were used as the substrate. The EHS collagen was obtained from Bethesda Research Laboratories (Gaithersburg, Maryland). The mouse skin collagen was a generous gift from Dr Sem Hin Phan (Department of Pathology, The University of Michigan). Plastic dishes were coated with these substrates in the same manner as was done with the human placental collagen. In addition to using acid-dried collagen, we also prepared hydrated collagen lattices [4] with the mouse skin collagen. This was done by preparing a $4 \mathrm{mg} / \mathrm{ml}$ solution of the collagen in $0.1 \mathrm{~mol} / \mathrm{L}$ acetic acid and then diluting the concentrated collagen solution with culture medium and neutralizing the $\mathrm{pH}$ with $\mathrm{NaOH}$. One millilitre of the neutralized collagen solution $(1 \mathrm{mg} / \mathrm{ml})$ was added to the bacteriological dishes and allowed to gel by incubating the dishes overnight at $37^{\circ} \mathrm{C}$ in a humidified atmosphere. Finally, untreated plastic culture dishes were also used as a substrate in certain experiments. Both cell culture dishes and bacteriological dishes were used.

\section{Measurement of cell attachment and spreading}

Cells to be used in the attachment and spreading assays were harvested from monolayer culture by trypsinization, washed four times in serum-free medium and 


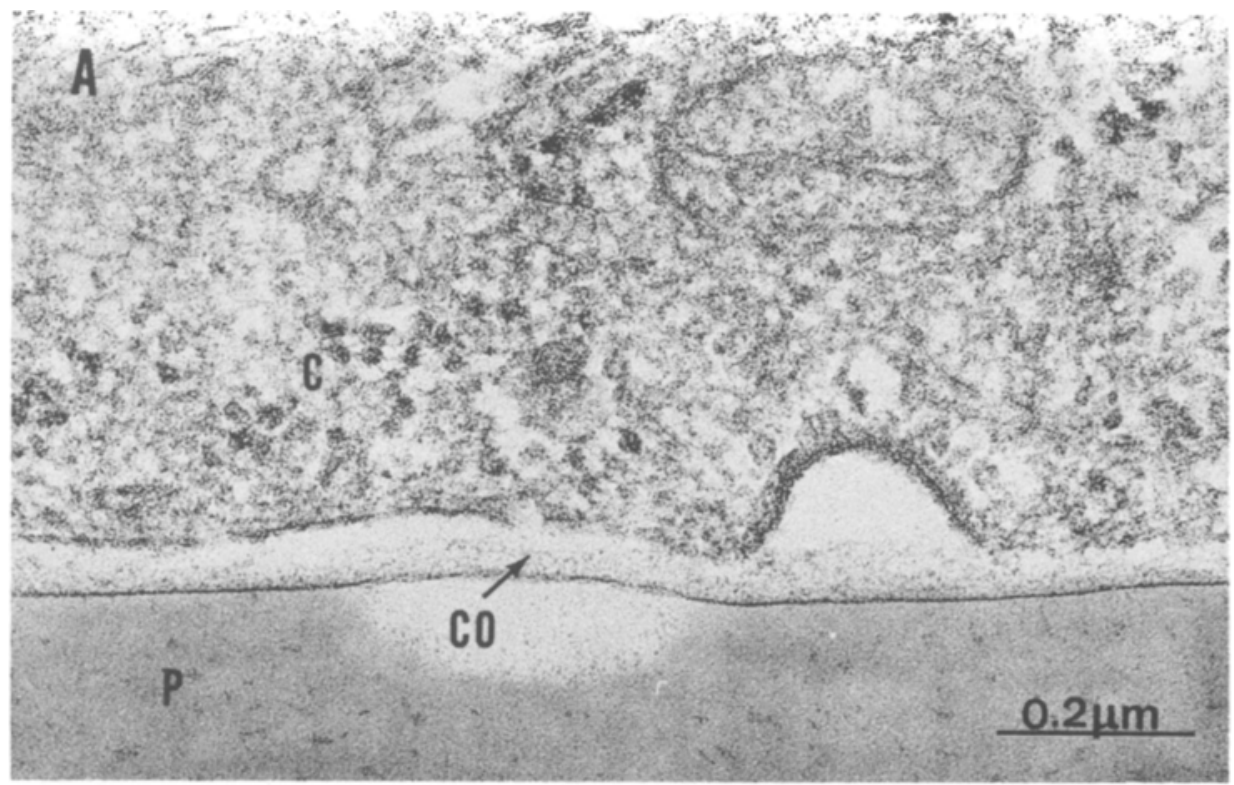

(a)

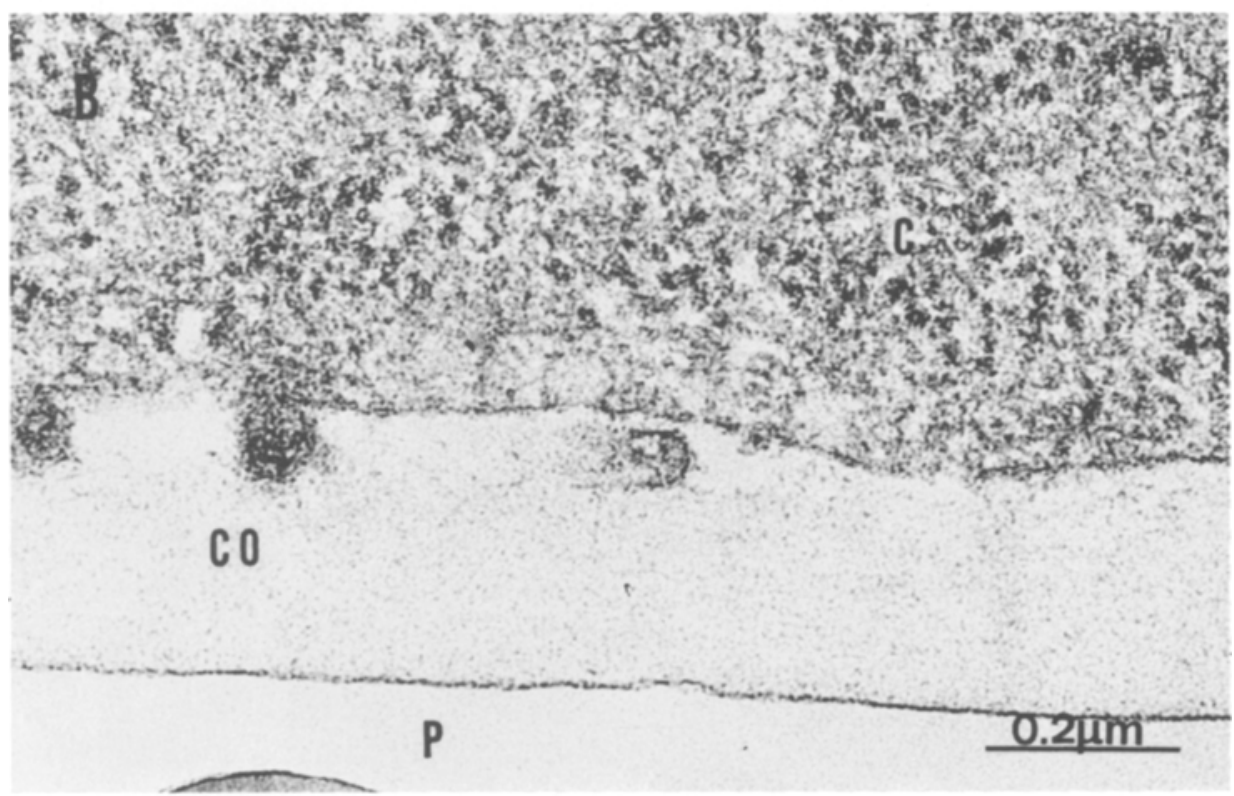

(b)

Figure 1. Tumor cells adhering to a coat made of $50 \mu \mathrm{g}$ of human placental type IV collagen dried on to $35 \mathrm{~mm}$ (diameter) plastic dishes. (A) A cell adhering to a coat of typical thickness. (B) A cell adhering to an exceptionally thick coat. The cells were allowed to adhere for $6 \mathrm{~h}$. C, cell; $\mathrm{CO}$, collagen; $\mathrm{P}$, plastic. 
added to the dishes at $2.5 \times 10^{5}$ cells per dish in RPMI-1640 medium with or without serum as indicated. The dishes were then incubated at $37^{\circ} \mathrm{C}$ in 5 per cent $\mathrm{CO}_{2}$. At various times later, the non-attached cells were removed from duplicate dishes. The attached cells were then harvested by trypsinization and enumerated using a Coulter Counter, model ZB. In some cases, the dishes were washed, flooded with 2 per cent glutaraldehyde in phosphate-buffered saline and used for phase-contrast photography. When uncoated plastic dishes were used, $200 \mu \mathrm{g} / \mathrm{ml}$ bovine serum albumin was included in the cell culture medium. In some experiments, medium with $0 \cdot 1$ per cent or 1.0 per cent fetal bovine serum was used.

We also determined the percentage of the attached cells which underwent spreading on the collagen-coated and plastic culture dishes. For this, the cells were added to the dishes as described above and incubated. At the appropriate times, the non-attached cells were removed and the dishes washed once with serum-free culture medium. A microscope with a calibrated grid in the eyepiece was used to make total cell counts and counts of spread cells. Several different areas on each dish were examined and 50-200 cells per field were counted. The percentage of spread cells was determined from this.

\section{Laminin binding to cells}

The ability of the laminin-deficient, low-malignant cells to bind laminin from solution was examined. The laminin-binding protocol was similar to that described in our recent report [16]. Briefly, the cells were harvested by trypsinization and then incubated in suspension in culture medium containing 10 per cent fetal bovine serum for a period of $4 \mathrm{~h}$. Following this, they were washed four times in serum-free medium and then incubated with the laminin under serum-free conditions. For this, $0-300 \mu \mathrm{g}$ laminin was incubated with $2 \times 10^{6}$ cells in a total volume of $0.35 \mathrm{ml}$. The incubation was carried out for a period of $1 \mathrm{~h}$. Then the cells were separated from the unbound laminin by centrifugation and washed four times. Following this, the amount of laminin bound to the cells was determined using an enzyme-linked lectin assay (ELLA) as previously described $[14,15]$. The ELLA makes use of an alkaline phosphatase-conjugated derivative of Griffonia simplicifolia $\mathrm{I} \mathrm{B}_{4}$ isolectin. It takes advantage of the high sensitivity provided by enzyme coupling and the strict specificity of this lectin for terminally linked $\alpha$-D-galactopyranosyl groups [17]. Since the laminin molecule contains this sugar as part of its carbohydrate structure [24] and the laminin-deficient cells have extremely small quantities of this sugar group on their surface [15], the binding of the lectin to the laminin-treated cells can be used to measure precisely the amount of laminin bound to the cells. All of the steps in the assay are carried out on cells in the viable state and therefore, the residues to which the lectin reacts are presumed to be on the cell surface. In brief, the cells are allowed to bind the lectin for $45 \mathrm{~min}$ at $37^{\circ} \mathrm{C}$. Following this, they are washed four times in isotonic buffer to remove unbound lectin, and then treated with the haptenic sugar, $\alpha$-methyl-D-galactopyranoside to release the specifically bound lectin from the cell surface. Aliquots of the released lectin are added to the wells of a microtiter plate and the enzyme reaction carried out in a manner analogous to that in ELISAs. Complete details of this assay procedure can be found in our recent reports [14-16].

\section{Results}

Cell attachment and spreading on the plastic culture dishes and collagen-coated dishes

The six cell lines were examined for attachment and spreading on the plastic bacteriological dishes and the dishes coated with human placental type IV collagen. 


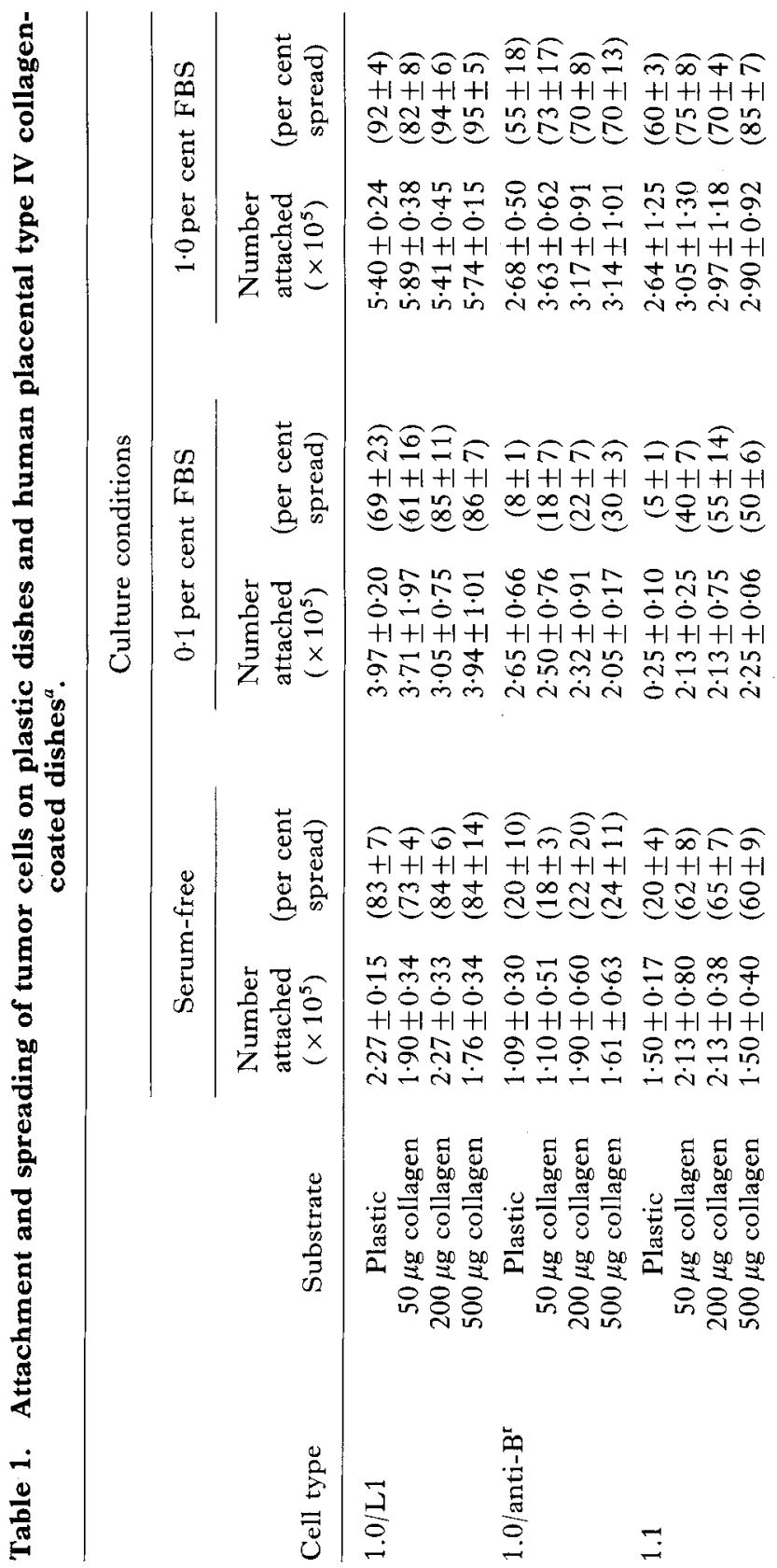




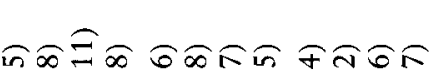
$+1+1+1+1+1+1+1+1+1+1+1+1$

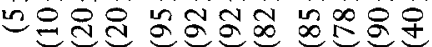

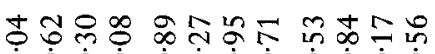
$\dot{-} \dot{0} \dot{0} \dot{0} \dot{0} \dot{0} \dot{0} 0 \dot{0} \dot{0}$ $+1+1+1+1+1+1+1+1+1+1+1+1$

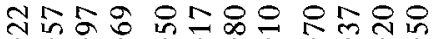
$\dot{\sim} \dot{\sim} \dot{\sim} \dot{-} \dot{+} \dot{+} \dot{+} \dot{\dot{d}} \dot{m} \dot{m} \dot{\sim}$

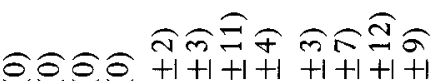

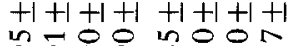

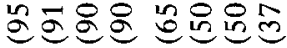

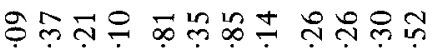
$0 \dot{0} \dot{0} \dot{0} \dot{0} \dot{0} \dot{0} \dot{0} \dot{0} \dot{0} \dot{0}$
$+1+1+1+1+1+1+1+1$

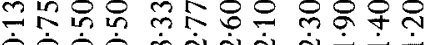

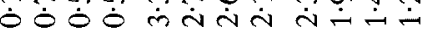

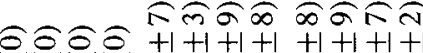
$+1+1+1+1+1+1+1+1$

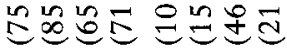

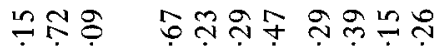

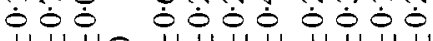
$+H+1+10 \quad H+H+1+1+H+H+1+1$

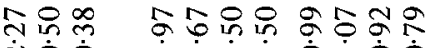
त் $\dot{0} \dot{\sim} \dot{\sim} \dot{-} \dot{0} \dot{0} \dot{0}$
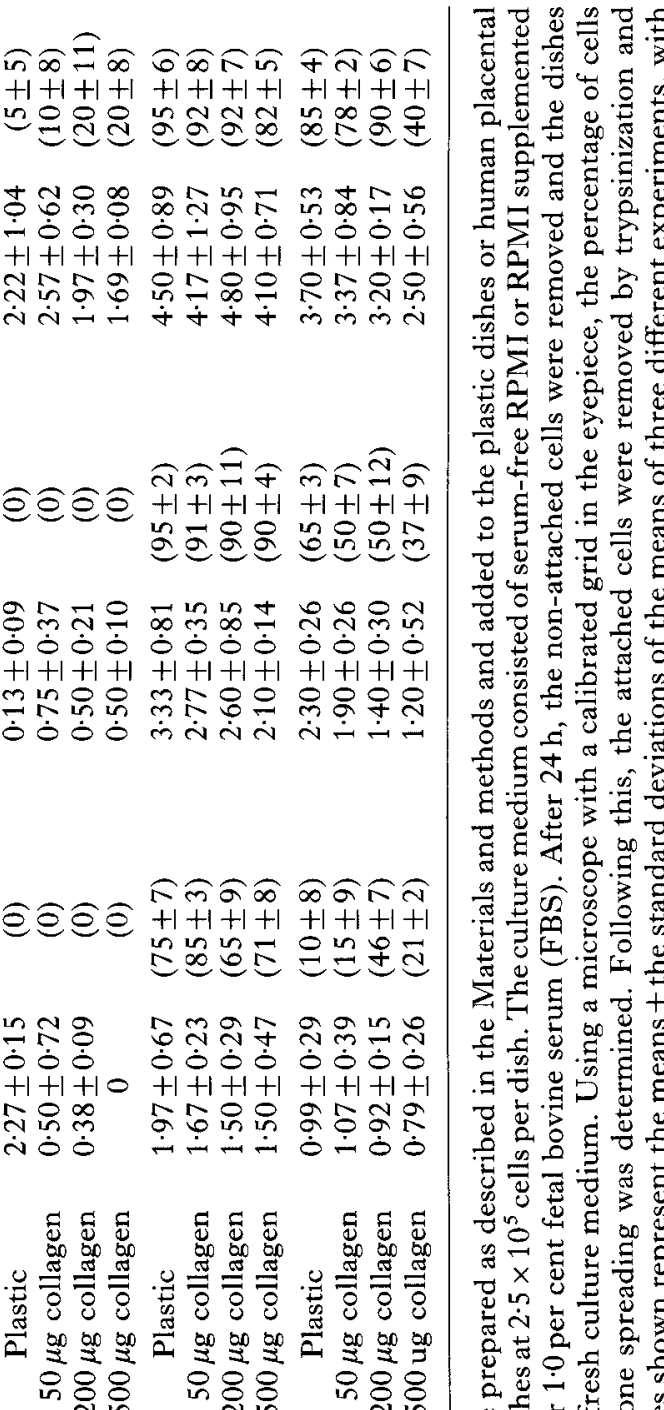

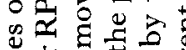

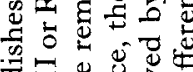

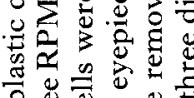

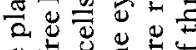

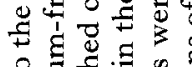

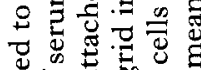

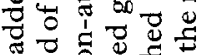

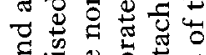

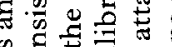
की

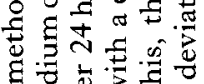

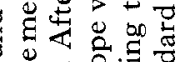

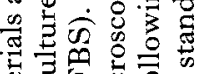

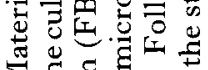

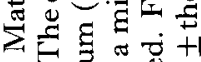

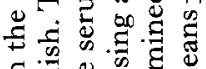
$\Xi \because \mathscr{~}$

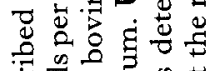

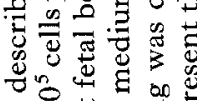

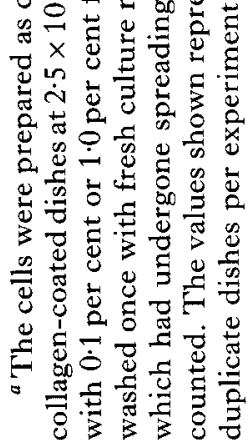




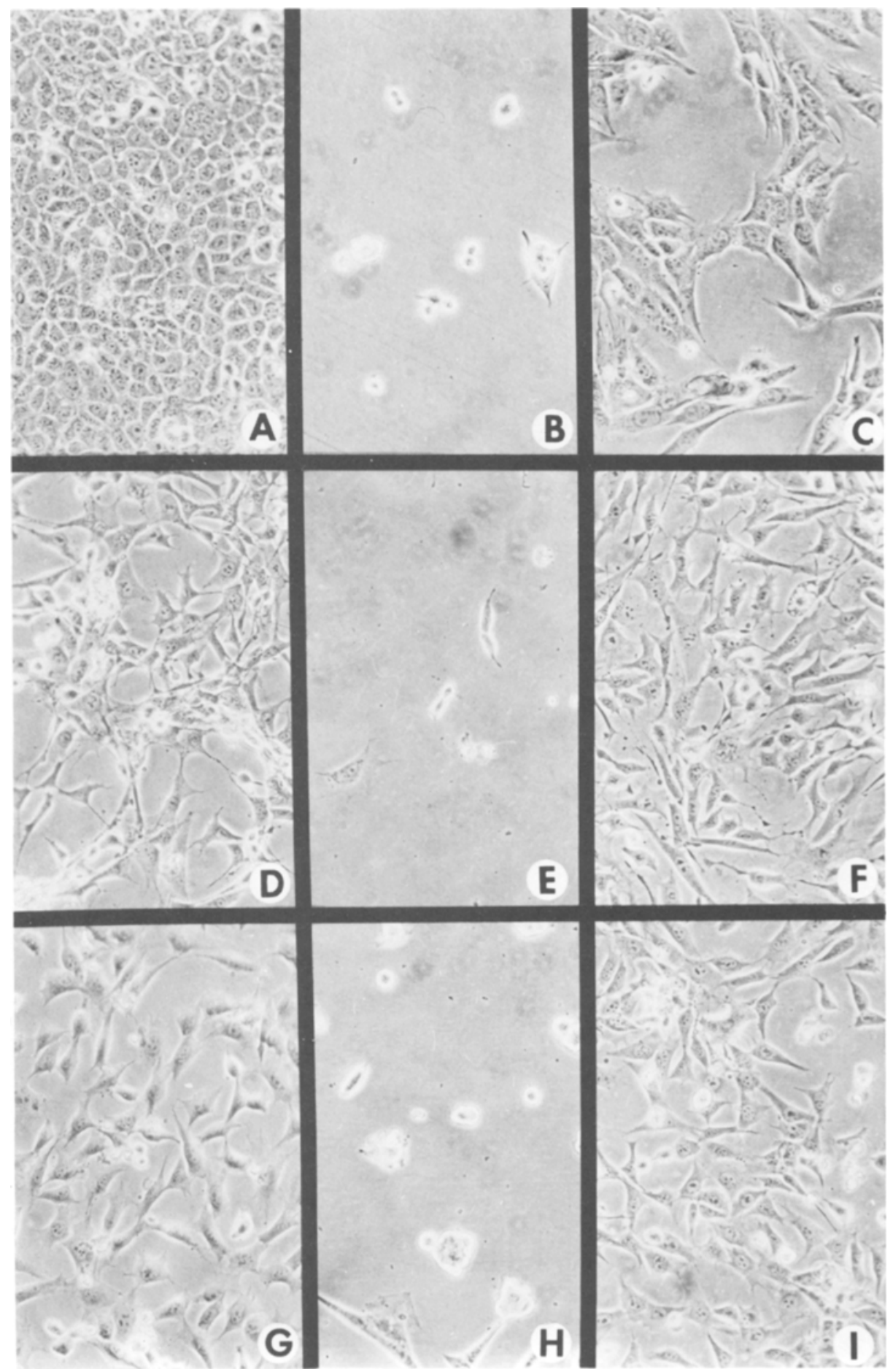

Figure 2. Phase-contrast photomicrographs of the laminin-positive cells and the laminindeficient cells in the presence and absence of $15 \mu \mathrm{g}$ laminin. The cells were allowed to attach to the collagen substrate and incubated for $48 \mathrm{~h}$. Following this, the non-attached cells were removed and the dishes flooded with 2 per cent glutaraldehyde in phosphatebuffered saline. $\times 300 .(\mathrm{A}-\mathrm{C})$ Cells from tumor 1.0. (D-F) Cells from tumor 1.1. (G-I) Cells from tumor 1.2. The laminin-positive cells are shown at the left $(A, D, G)$. The laminin-deficient cells in the absence of exogenous laminin are shown in the middle $(\mathrm{B}, \mathrm{E}, \mathrm{H})$ and the laminin-deficient cells in the presence of exogenous laminin are shown at the right $(\mathrm{C}, \mathrm{F}, \mathrm{I})$. 
Table 2. Attachment and spreading of tumor cells on dishes coated with EHS sarcoma (type IV) collagen, mouse skin (type I) collagen and collagen gels prepared from mouse skin (type I) collagen ${ }^{a}$.

\begin{tabular}{|c|c|c|c|c|c|c|}
\hline \multirow[b]{3}{*}{ Cell type } & \multicolumn{6}{|c|}{ Substrate } \\
\hline & \multicolumn{2}{|c|}{ EHS collagen $^{b}$} & \multicolumn{2}{|c|}{ Mouse skin collagen $^{b}$} & \multicolumn{2}{|c|}{ Mouse skin collagen gel } \\
\hline & $\begin{array}{l}\text { Number of } \\
\text { cells attached }\end{array}$ & $\begin{array}{l}\text { (per cent } \\
\text { spread) }\end{array}$ & $\begin{array}{l}\text { Number of } \\
\text { cells attached }\end{array}$ & $\begin{array}{l}\text { (per cent } \\
\text { spread) }\end{array}$ & $\begin{array}{l}\text { Number of } \\
\text { cells attached }\end{array}$ & $\begin{array}{l}\text { (per cent } \\
\text { spread) }\end{array}$ \\
\hline $1.0 / \mathrm{L} 1$ & $1 \cdot 78 \pm 0 \cdot 35$ & $83 \pm 11$ & $0 \cdot 85 \pm 0 \cdot 15$ & $90 \pm 5$ & $2 \cdot 37 \pm 0 \cdot 50$ & $65 \pm 17$ \\
\hline 1.0/anti-B ${ }^{r}$ & $1.95 \pm 0.75$ & $5 \pm 5$ & $1 \cdot 13 \pm 0 \cdot 21$ & $10 \pm 5$ & $2 \cdot 15 \pm 0 \cdot 25$ & $23 \pm 12$ \\
\hline $\begin{array}{l}1.1 \\
1.1 / \text { anti-B }\end{array}$ & $\begin{array}{l}0 \cdot 95 \pm 0 \cdot 51 \\
0 \cdot 60 \pm 0 \cdot 28\end{array}$ & $\frac{68 \pm 20}{0}$ & & $\mathrm{ND}^{d}$ & ND & \\
\hline $\begin{array}{l}1.2 \\
1.2 / \text { anti-B }\end{array}$ & $\begin{array}{l}1 \cdot 31 \pm 0 \cdot 17 \\
1 \cdot 00 \pm 0 \cdot 75\end{array}$ & $88 \pm 11$ & & ND & $\mathrm{ND}$ & \\
\hline
\end{tabular}

${ }^{a}$ The three substrates were prepared as described in the Materials and methods section. The cells $\left(2.5 \times 10^{5} /\right.$ dish $)$ were added at time zero and cell attachment and spreading were quantified $24 \mathrm{~h}$ later. (Cells were harvested from the collagen gels after digestion of the collagen with bacterial collagenase.) The values shown are mean values \pm the differences between the mean values and the individual values in duplicate experiments. Duplicate dishes were used in each experiment.

${ }^{b}$ Serum-free RPMI-1640 medium was used.

${ }^{c}$ RPMI-1640 medium supplemented with 10 per cent fetal bovine serum was used.

${ }^{d} \mathrm{ND}=$ not determined

Data obtained after $24 \mathrm{~h}$ from several experiments are presented in table 1 . Overall, it can be seen that under serum-free conditions, a higher percentage of the highly malignant cells attached and spread than the corresponding low-malignant cells on both the plastic dishes and the collagen-coated dishes. In the presence of low serum concentrations $(0 \cdot 1$ per cent $)$, consistent differences were also observed, and it was only at $1 \cdot 0$ per cent serum that these differences began to disappear. It is obvious that in some groups, cells have divided during $24 \mathrm{~h}$ in the presence of serum. Figure 2 shows a series of photomicrographs comparing the attachment and spreading of the three highly malignant lines (in the left-hand portion) and the three corresponding low-malignant lines (in the center). In other experiments, type IV collagen prepared from the EHS sarcoma or type I collagen from mouse skin were used in place of the human placental collagen. Differences in attachment and spreading were also observed on these substrates. Differences in spreading activity were especially dramatic. Virtually none of the low-malignant cells spread on these substrates while a significant amount of spreading was detected with all three of the highly malignant lines (table 2). Finally, we examined the attachment and spreading activities of the 1.0/L1 cells and 1.0/anti- $\mathrm{B}^{\mathbf{r}}$ cells on the collagen gels prepared from the mouse skin (type I) collagen. 'These experiments, which were carried out in medium containing 10 per cent fetal bovine serum, showed that nearly all of the cells from both lines attached to the collagen substrate. However, as with the other substrates, the highmalignant cells spread to a greater extent than the low-malignant cells (table 2). Accompanying the attachment and spreading of the high malignant cells was a contraction of the hydrated collagen substrate. By one day after plating, the hydrated collagen lattice was reduced to a thin disk floating in the culture medium. In their effects on the hydrated collagen lattice, the high-malignant tumor cells resemble normal fibroblasts [4]. 
The data presented in tables 1 and 2 were obtained by assaying for cell attachment and spreading one day after plating. When the cells were harvested from the plastic dishes or collagen-coated dishes two or three days after plating (on serumfree medium) there was a significant increase in the number of $1.0 / \mathrm{L} 1$ cells and 1.1 cells over the amount initially added. Although the numbers varied from experiment to experiment, we often obtained up to $10^{6}$ cells per dish (i.e., two cell doublings). The low malignant lines from the same tumors did not show this increase under serum-free conditions. The total number of these cells remained constant and they gradually detached from the substrate during long-term incubation under serumfree conditions. With the cells from tumor 1.2, neither the highly malignant or lowmalignant cells showed significant proliferative capacity under serum-free conditions.

\section{Effects of laminin on tumor cell attachment and spreading}

The low-malignant cells were examined for attachment and spreading on the plastic dishes and human placental collagen-coated dishes in the presence of laminin. The cells were prepared in the normal way and added to the dishes along with $15 \mu \mathrm{g}$ laminin under serum-free conditions. The addition of laminin dramatically enhanced attachment and spreading. Quantitative results are shown in table 3 . Photomicrographs depicting this are shown in the right-hand portion of figure 2.

Since exogenous laminin was found to promote attachment and spreading of the low-malignant cells, anti-laminin antibodies were used in an effort to block the attachment of the high malignant cells. The IgG fraction of the anti-laminin serum was prepared as described in the Materials and methods section and 50-150 $\mu \mathrm{g}$ of the immunoglobulin were added to the dishes along with the cells. The $1.0 / \mathrm{L} 1$ cells were used in these experiments. Although inhibition was not complete, the rabbit anti-

Table 3. Effects of laminin on the attachment and spreading of the low-malignant tumor cells ${ }^{a}$.

\begin{tabular}{llcc}
\hline Cell type & Substrate & $\begin{array}{c}\text { Number of cells } \\
\text { attached }\left(\times 10^{5}\right)\end{array}$ & Per cent spread \\
\hline $1.0 /$ anti-B $^{\mathrm{r}}$ & Plastic & $0 \cdot 65 \pm 0 \cdot 20$ & 0 \\
& Plastic/laminin & $2 \cdot 46 \pm 0 \cdot 75$ & $90 \pm 8$ \\
& Collagen & $1 \cdot 41 \pm 0 \cdot 61$ & $18 \pm 5$ \\
& Collagen/laminin & $2 \cdot 46 \pm 0 \cdot 70$ & $92 \pm 7$ \\
$1.1 /$ anti-B $^{\mathbf{r}}$ & Plastic & $1 \cdot 70 \pm 0 \cdot 35$ & 0 \\
& Plastic/laminin & $2 \cdot 25 \pm 0 \cdot 41$ & $85 \pm 10$ \\
& Collagen & $0 \cdot 35 \pm 0 \cdot 10$ & 0 \\
$1.2 /$ anti-B & Collagen/laminin & $1 \cdot 50 \pm 0 \cdot 35$ & $75 \pm 8$ \\
& Plastic & $0 \cdot 85 \pm 0 \cdot 25$ & $25 \pm 15$ \\
& Plastic/laminin & $2 \cdot 25 \pm 0 \cdot 17$ & $90 \pm 18$ \\
& Collagen & $1 \cdot 75 \pm 0 \cdot 62$ & $45 \pm 17$ \\
& Collagen/laminin & $2 \cdot 31 \pm 0 \cdot 36$ & $75 \pm 12$
\end{tabular}

${ }^{a}$ The cells were prepared as described in Materials and methods and added $\left(2.5 \times 10^{5} / \mathrm{dish}\right)$ to the plastic dishes or to the dishes coated with $50 \mu \mathrm{g}$ of the human placental type IV collagen in the absence of serum. Laminin was added directly to the dishes $(15 \mu \mathrm{g} / \mathrm{dish})$ along with the cells. Twenty four hours later cell attachment and cell spreading were determined as described in the legend to table 1 . The values shown are the mean values \pm the standard deviation of the means of three different experiments. Duplicate dishes were used in each experiment. 
laminin antibodies did inhibit attachment. Inhibition ranged from 25 per cent \pm 5 per cent at $50 \mu \mathrm{g}$ of protein/dish to 45 per cent \pm 3 per cent at $150 \mu \mathrm{g}$ (means \pm standard errors based on duplicate samples in two separate experiments). Normal rabbit IgG did not inhibit attachment.

\section{Attachment and spreading of cells after treatment with laminin in suspension}

It is possible that laminin-mediated attachment and spreading occurred following binding of the laminin to the substrate first and then to the cells or following binding to the cells first and then to the substrate. Obviously, the two possibilities are not mutally exclusive. However, in an effort to 'mimic' the behaviour of the highly malignant cells (which express laminin-like antigens on their surface), the lowmalignant $\left(1.0 /\right.$ anti- $\left.\mathrm{B}^{\mathrm{r}}\right)$ cells were treated with laminin in suspension, separated from the unbound laminin, and then examined for ability to attach and spread. Simultaneously, they were assessed for bound laminin using the ELLA technique (table 4). The cells treated in this manner were able to bind laminin while in suspension, and as the amount of bound laminin increased, the ability to attach and spread also increased.

\section{Discussion}

The attachment of tumor cells to host tissue structures occurs at several steps in the invasion and metastatic processes [9]. This is probably a critical event because once the cells have become attached, they are able to carry out other functions such as active movement $[30,36,38]$, host tissue destruction $[6,9,25,30]$ and proliferation [3] which are necessary for successful metastasis formation. Additionally, in the case of circulating tumor cells, the attachment of the cells to the vascular wall allows the cells to get out of the circulation, which is a hostile environment. It would not seem surprising in the light of this to find that cells which are highly adhesive would be more metastatic than cells which are less adhesive and previous investigations by several groups have supported this concept $[18-22,27,37,40]$. In this report we show that highly malignant tumor cell lines from three different tumors are more

Table 4. Attachment and spreading of untreated and laminin-treated $1 \cdot 0 / a^{-1}+\mathbf{B}^{\mathrm{r}}$ cells ${ }^{a}$.

\begin{tabular}{lcccc}
\hline Cell type & $\begin{array}{c}\text { Amount of } \\
\text { laminin added }\end{array}$ & $A_{405}$ & $\begin{array}{c}\text { Number of cells } \\
\text { attached }\left(\times 10^{5}\right)\end{array}$ & Per cent spread \\
\hline $1.0 /$ anti-B & 0 & $0 \cdot 009 \pm 0 \cdot 003$ & $0 \cdot 85 \pm 0 \cdot 20$ & 0 \\
& 75 & $0 \cdot 128 \pm 0 \cdot 022$ & $1 \cdot 05 \pm 0 \cdot 17$ & $35 \pm 10$ \\
& 150 & $0 \cdot 205 \pm 0 \cdot 038$ & $1 \cdot 50 \pm 0 \cdot 25$ & $80 \pm 12$ \\
$1.0 /$ L1 & 300 & $0 \cdot 588 \pm 0 \cdot 067$ & $2 \cdot 04 \pm 0 \cdot 85$ & $77 \pm 9$ \\
& 0 & $1 \cdot 123 \pm 0 \cdot 260$ & ND & ND \\
\hline
\end{tabular}

${ }^{a}$ The 1.0/anti- $\mathrm{B}^{\mathrm{r}}$ cells were harvested from culture and treated with laminin as described in Materials and methods. After washing the cells four times they were divided into two pools. With the cells in the first pool, the relative amount of laminin bound to the cells was determined using the enzyme-linked lectin assay. With the second pool of cells, cell attachment and spreading were determined. The $A_{405}$ values are means \pm standard deviations of triplicate samples in a single experiment. The adherence and spreading values are means \pm differences between the mean values and the individual values in a single experiment. The experiment was run twice with very similar results. 
adherent to plastic culture dishes and collagen-coated dishes than are low-malignant cell lines derived from the same tumors. Furthermore, there is a difference in behavior of the cells once they have attached. The highly malignant cells have the tendency to spread and flatten out while the low-malignant cells demonstrate much less spreading. In addition, some of the highly malignant cells undergo proliferation even in the absence of serum whereas none of the low-malignant cells do. Under these conditions, the low-malignant cells detach with time. These differences between the highly malignant and low-malignant tumor lines were observed on plastic dishes and dishes coated with collagen from a variety of sources. Thus, the differences in attachment and spreading do not show substrate specificity. Previous studies have suggested that malignant tumor cells demonstrate specific adhesive interactions with target structures in organs to which they metastasize [20,21]. How the present findings relate to this is unknown but one can envisage a model of metastasis involving both specific recognition factors and non-specific capacity for adhesion.

The cellular and molecular basis of tumor cell adhesiveness is not fully understood. Obviously, tumor cells may have evolved a number of distinct mechanisms. Recent studies have shown that a number of different types of tumor cells have surface receptors for laminin [10-12, 23, 28]. Laminin, which is an attachment factor for several types of cells $[1,27,29,35,39]$, is found in conjunction with type IV collagen in basement membranes [1, 31]. It may be suggested, therefore, that the presence of laminin receptors on the cell surface provides a mechanism whereby invading tumor cells can interact with the basement membrane components of the tissue being invaded.

Our studies also suggest a role for laminin. However, our findings indicate that, at least in the murine fibrosarcoma model, it is the presence of laminin (or laminin-like material) on the cell surface rather than the presence of unfilled laminin receptors that correlates with adhesiveness. The highly malignant cells used in the present studies have previously been shown to express antigens on their surface which crossreact with laminin. This was initially shown by immunofluorescence on cells in the viable state with all three lines and by enzyme-linked immunosorbent assay with purified components from these cells $[34,35]$. This was confirmed in the $1.0 / \mathrm{L} 1$ cells by demonstrating that purified membrane fractions could elicit the formation of antibodies in rabbits which crossreacted with laminin by ELISA and also by demonstrating cell surface reactivity with the anti-laminin antibodies by immunoperoxidase/electron microscopy [13]. These approaches provide compelling evidence for the existence of a laminin-like antigen on the surface of the highly malignant cells. The same approaches with the low-malignant cells show no evidence of a similar material $[13,34,35]$. Whether the crossreactive material on the highly malignant cells is intact laminin cannot be determined from these approaches. However, using metabolic labeling followed by immunoprecipitation with antilaminin antibodies it was demonstrated that the cells secrete into the culture medium, a moiety which comigrates with intact laminin in SDS-polyacrylamide gels [13]. Under reducing conditions, this moiety has protein bands at $M_{\mathrm{r}} 200000$ and 400000 . Thus, on the basis of these observations we suggest that there are differences between the high- and low malignant cells in the expression of cell surface laminin (or laminin-like substance). This difference may contribute to dissimilarity in in vivo behavior. It should not be implied from this that the differences in laminin expression account completely for the dissimilarity in 
biological behavior. A number of other, unrelated cell surface differences between these cells may also exist and additional studies will need to be done before all of these differences are known. It is interesting in this regard, however, that recent studies by Jellum et al. [5] using high-resolution two-dimensional electrophoresis showed that the protein patterns of the $1.0 / \mathrm{L} 1$ cells and $1.0 /$ antiB $^{\mathrm{r}}$ cells are very similar overall. It should also be noted that examination of the highly malignant and low-malignant cells for the presence of surface fibronectin indicates that there is some of this material on both groups of cells (unpublished observation).

Whether or not the differences in laminin expression are mainly responsible for the biological dissimilarity between the high- and low-malignant cells, these differences can be reduced in the presence of exogenous laminin. The addition of exogenous laminin to the low-malignant cells caused these cells to attach rapidly and spread on the plastic dishes or collagen-coated dishes. This was shown when the laminin was added directly to the substrate along with the cells, but more importantly, it was also shown when the cells were allowed to bind the laminin in solution and then separated from the unbound material. This suggests that when the normally laminin-deficient low-malignant cells are artificially 'reconstituted' with exogenous laminin, their adherence and spreading characteristics come to resemble those of the high-malignant cells which express laminin-like antigens intrinsically. That this may be directly related to metastatic activity is inferred by our recent finding that the laminin-treated low-malignant cells form a much greater number of lung tumors after intravenous injection than do untreated low-malignant cells [12]. Even after laminin treatment, however, the lung colonizing ability is not as great as that of the high-malignant cells, indicating that metastasis is a multi-step process and that laminin-independent events no doubt occur.

In summary then, the findings described here, along with previously published findings, suggest that there are two possible ways that the presence of laminin receptors on tumor cells may facilitate their attachment to host tissue structures. One involves the interaction of the tumor cells directly with exposed laminin in the extracellular matrix via high-affinity receptors for laminin on the cell surface. A second one involves the binding of laminin (perhaps endogenously synthesized) by these same receptors and then interaction with host tissue structures mediated by the presence of cell-surface laminin. Obviously, these two ways are not unrelated or mutually exclusive and both may, as suggested by correlative studies, play a role in metastasis formation.

\section{Acknowledgments}

This study was supported in part by NIH grants CA 20324, CA36132 and by a grant from the Milheim Foundation for Cancer Research. Dr Ivar A. Grimstad is a Research Fellow of the Norwegian Research Council for Science and the Humanities. We thank Patricia Perone, Kari Anne Andreassen and Aileen Murdoch Larsen for excellent technical assistance.

\section{References}

[1] Couchman, J. R., Нook, M., Rees, D. A., and Timpl, R., 1983, Adhesion, growth and matrix production by fibroblasts on laminin substrates. Journal of Cell Biology, 96, $177-183$.

[2] Glanville, R. W., Rauter, A., and Fietzek, P. P., 1979, Isolation and characterization of a native placental basement-membrane collagen and its component $\alpha$ chains. European Journal of Biochemistry, 95, 383-389. 
[3] Gospodarowicz, D., Delgado, D., and Vlodavsky, I., 1980, Permissive effect of the extracellular matrix on cell proliferation in vitro. Proceedings of the National Academy of Sciences, U.S.A., 77, 4094-4098.

[4] Grinnell, F., and Lamke, C. R., 1984, Reorganization of hydrated collagen lattices by human skin fibroblasts. Journal of Cell Science, 66, 51-63.

[5] Jellum, E., Thorsrud, A. K., Vatn, M. H., Grimstad, I. A., Brennhovd, I., Tveit, K. M., and PiHL, A., 1984, Detection of cancer-related proteins by two-dimensional electrophoresis. Annals of the New York Academy of Sciences, 428, 173-184.

[6] Johnson, K. J., and Varani, J., 1981, Substrate hydrolysis by immune complexactivated neutrophils: Effect of physical presentation of complexes and protease inhibitors. Journal of Immunology, 127, 1875-1879.

[7] Levy, H. B., and Sober, H. A., 1960, A simple chromatographic method for preparation of gamma globulin. Proceedings of the Society for Experimental Biology and Medicine, 103, $250-254$.

[8] Lrotta, L. A., Tryggvason, K., Garbisa, S., Hast, I. R., Foltz, C., and Shafie, S., 1980, Metastatic potential correlates with enzymatic degradation of basement membrane collagen. Nature, 184, 67-68.

[9] Liotta, L. A., Rao, C. N., and Barsky, S. H., 1983, Tumor invasion and the extracellular matrix. Laboratory Investigation, 49, 636-649.

[10] Malinoff, H., McCoy, P., Varani, J., and Wrcha, M., 1982, Metastatic potential of murine fibrosarcoma cells correlates with endogenous surface receptor-bound laminin. Journal of Cell Biology, 95, 126 a.

[11] Malinoff, H. L., and Wicha, M. S., 1983, Isolation of a cell surface receptor protein for laminin from murine fibrosarcoma cells. Journal of Cell Biology, 96, 1475-1479.

[12] Malinoff, H. L., McCoy, J. P., Varani, J., and Wicha, M., 1984, Metastatic potential of murine fibrosarcoma cells is influenced by cell surface laminin. International Journal of Cancer, 33, 651-655.

[13] McCoy, J. P., Lloyd, R., Wicha, M. S., and Varani, J., 1984, Identification of a laminin-like substance on the surface of high malignant murine fibrosarcoma cells. Journal of Cell Science, 65, 139-151.

[14] McCoy, J. P., Varani, J., and Goldstein, I. J., 1983, Enzyme-linked lectin assay (ELLA): Use of alkaline-phosphatase-conjugated $G$. simplicifolia $\mathbf{B}_{4}$ isolectin for the detection of $\alpha$-D-galactopyranosyl end groups. Analytical Biochemistry, 130, 437-444.

[15] McCoy, J. P., Varani, J., and Goldstein, I. J., 1984, Enzyme-linked lectin assay (ELLA). II. Detection of carbohydrate groups on the surface of unfixed cells. Experimental Cell Research, 151, 96-103.

[16] McCoy, J. P., Goldstein, I. J., and Varani, J., 1984, Tumor cell carbohydrates: Investigation of cells with varying metastatic potential using an enzyme-linked lectin assay (ELLA). Tumor Biology (in the press).

[17] Murphy, L. A., and Goldstein, I. J., 1977, Five $\alpha$-D-galactopyranosyl-binding isolectins from Bandeiraea simplicifolia seeds. Journal of Biological Chemistry, 252, $4739-4742$.

[18] Murray, J. C., Liotta, L., Rennard, S. I., and Martin, G. R., 1980, Adhesion characteristics of murine metastatic and non-metastatic tumor cells in vitro. Cancer Research, 40, 347-351.

[19] Murray, J. C., Liotta, L. A., and Terranova, V. P., 1982, Attachment of metastatic tumor cells to collagen. In: Tumor Invasion and Metastasis, Developments in Oncology. Vol. 7, edited by L. A. Liotta and I. R. Hart (The Hague: Martinus Nijhoff), pp. 309318.

[20] Netland, P. A., and Zetter, B. R., 1984, Organ-specific adhesion of metastatic tumor cells in vitro. Science, 224, 1113-1115.

[21] Nicolson, G. L., and Winkelhake, J. L., 1975, Organ specificity of blood-borne metastases as determined by cell adhesion. Nature, 255, 230-232.

[22] Poste, G., and Fidler, I. J., 1980, The pathogenesis of cancer metastasis. Nature, 283, $139-146$.

[23] Rao, N. C., Barsky, S. H., Terranova, V. P., and Liotta, L. A., 1983, Isolation of a tumor cell laminin receptor. Biochemical and Biophysical Research Communications, 111, $804-808$. 
[24] Shibata, S., Peters, B. P., Roberts, D. D., Goldstein, I. J., and Liotta, L. A., 1982, Isolation of laminin by affinity chromatography on immobilized Griffonia simplicifolia I lectin. FEBS Letters, 142, 194-198.

[25] Sloane, B. F., Dunn, J. R., and Honn, K. V., 1981, Lysosomal cathepsin B: Correlation with metastatic potential. Science, 212, 1151-1153.

[26] Sykes, B. C., and Bailey, A. J., 1971, Molecular weight heterogeneity of the $\alpha$-chain sub-units of collagen. Biochemical and Biophysical Research Communications, 43, 340 345.

[27] Terranova, V. P., Liotta, L. A., Russo, R. G., and Martin, G. R., 1982, Role of laminin in the attachment and metastasis of murine tumor cells. Cancer Research, 42, 2265-2269.

[28] Terranova, V. P., Rao, C. N., Kalebic, T., Margulies, I. M., and Liotta, L. A., 1983, Laminin receptor on human breast carcinoma cells. Proceedings of the National Academy of Sciences, U.S.A., 80, 444448.

[29] Terranova, V. P., Rohrbach, D. H., and Martin, G. R., 1980, Role of laminin in the attachment of PAM 212 (epithelial) cells to basement membrane collagen. Cell, 22, $719-726$.

[30] Thorgeirsson, U. P., Liotta, L. A., Kalebic, T., Margulies, I. M., Thomas, K., Rios-Candelore, M., and Russo, R. G., 1982, Effect of natural protease inhibitors and chemoattractant on tumor cell invasion in vitro. Journal of the National Cancer Institute, 69, 1049-1054.

[31] Timpl, R., Rohde, H., Robey, P. G., Rennard, S. I., Foidart, F. M., and MARTIN, G. R., 1979, Laminin - a glycoprotein from basement membranes. Journal of Biological Chemistry, 254, 9933-9937.

[32] Varani, J., OrR, W., and Ward, P. A., 1979, Comparison of subpopulations of tumor cells with altered migratory activity, attachment characteristics, enzyme levels and in vivo behavior. European Journal of Cancer, 15, 585-592.

[33] VARani, J., ORR, W., and WARD, P. A., 1979, Hydrolytic enzyme activities, migratory activity and in vivo growth and metastatic potential of recent tumor isolates. Cancer Research, 39, 2376-2380.

[34] Varani, J., Lovett, E. J., Wincha, M., Malinoff, H., and McCoy, J. P., 1983, Cell surface $\alpha$-D-galactopyranosyl end groups: Use as a marker in the isolation of murine tumor cell lines with varying cancer-causing potential. Journal of the National Cancer Institute, 71, 1281-1287.

[35] Varani, J., Lovett, E. J., McCoy, J. P., Shibata, S., Maddox, D. E., Goldstein, I. J., and WICHA, M., 1983, Differential expression of a laminin-like substance by high and low metastatic tumor cells. American Journal of Pathology, 111, 27-34.

[36] VARANi, J., and LovetT, E. J., 1982, Phenotypic stability of murine tumor cells in vitro and in vivo. Journal of the National Cancer Institute, 68, 957-962.

[37] Varani, J., LovetT, E. J., Elgebaly, S., Lundy, J., and Ward, P. A., 1980, In vitro and in vivo adherence of tumor cell variants correlated with tumor formation. American Journal of Pathology, 101, 345-352.

[38] Varani, J., Wass, J., Piontek, G. E., and Ward, P. A., 1981, Chemotactic factorinduced adherence of tumor cells. Cell Biology International Reports, 5, 525-530.

[39] Vlodavsky, I., and Gospodarowicz, D., 1981, Respective roles of laminin and fibronectin in adhesion of human carcinoma and sarcoma cells. Nature, 289, 304-306.

[40] Winkelmake, J. L., and Nicolson, G. L., 1976, Determination of adhesive properties of variant metastatic melanoma cells to $B A L B / 3 T 3$ cells and their virus-transformed derivatives by a monolayer attachment assay. Journal of the National Cancer Institute, 56, 285-311. 